\title{
EDS1-Dependent Cell Death and the Antioxidant System in Arabidopsis Leaves is Deregulated by the Mammalian Bax
}

\author{
Maciej Jerzy Bernacki ${ }^{1}$, Weronika Czarnocka ${ }^{2,3}{ }^{\circledR}$, Magdalena Zaborowska ${ }^{2}{ }^{\circledR}$, \\ Elżbieta Różańska ${ }^{3}{ }^{\circledR}$, Mateusz Labudda ${ }^{4}{ }^{\oplus}$, Anna Rusaczonek ${ }^{2,3}$, Damian Witoń ${ }^{2}$ \\ and Stanisław Karpiński ${ }^{2, *}$ (i) \\ 1 Institute of Technology and Life Sciences, Falenty, Al. Hrabska 3, 05-090 Raszyn, Poland; \\ mjbernacky@gmail.com \\ 2 Department of Plant Genetics, Breeding and Biotechnology, Institute of Biology, Warsaw University of \\ Life Sciences, Nowoursynowska Street 159, 02-776 Warsaw, Poland; \\ weronika_czarnocka@sggw.edu.pl (W.C.); magdazaborowskaa@gmail.com (M.Z.); \\ anna_rusaczonek@sggw.edu.pl (A.R.); damiankamilwiton@gmail.com (D.W.) \\ 3 Department of Botany, Institute of Biology, Warsaw University of Life Sciences, Nowoursynowska Street 159, \\ 02-776 Warsaw, Poland; elzbieta_rozanska@sggw.edu.pl \\ 4 Department of Biochemistry and Microbiology, Institute of Biology, Warsaw University of Life Sciences, \\ Nowoursynowska Street 159, 02-776 Warsaw, Poland; mateusz_labudda@sggw.edu.pl \\ * Correspondence: stanislaw_karpinski@sggw.edu.pl
}

Received: 7 October 2020; Accepted: 6 November 2020; Published: 10 November 2020

\begin{abstract}
Cell death is the ultimate end of a cell cycle that occurs in all living organisms during development or responses to biotic and abiotic stresses. In the course of evolution, plants and animals evolve various molecular mechanisms to regulate cell death; however, some of them are conserved among both these kingdoms. It was found that mammalian proapoptotic BCL-2 associated X (Bax) protein, when expressed in plants, induces cell death, similar to hypersensitive response (HR). It was also shown that changes in the expression level of genes encoding proteins involved in stress response or oxidative status regulation mitigate Bax-induced plant cell death. In our study, we focused on the evolutional compatibility of animal and plant cell death molecular mechanisms. Therefore, we studied the deregulation of reactive oxygen species burst and HR-like propagation in Arabidopsis thaliana expressing mammalian Bax. We were able to diminish Bax-induced oxidative stress and HR progression through the genetic cross with plants mutated in ENHANCED DISEASE SUSCEPTIBILITY 1 (EDS1), which is a plant-positive HR regulator. Plants expressing the mouse Bax gene in eds1-1 null mutant background demonstrated less pronounced cell death and exhibited higher antioxidant system efficiency compared to Bax-expressing plants. Moreover, eds1/Bax plants did not show HR marker genes induction, as in the case of the Bax-expressing line. The present study indicates some common molecular features between animal and plant cell death regulation and can be useful to better understand the evolution of cell death mechanisms in plants and animals.
\end{abstract}

Keywords: cell death; Bax; EDS1; ROS; hypersensitive response

\section{Introduction}

Cell death is a process occurring in all multicellular organisms. It is crucial in the development senescence and growth of both animals and plants [1,2]. Moreover, it is important in response to various stress factors and is engaged in different types of diseases and immune defence [3] and in acclimatory responses [4]. In the course of evolution, plants and animals have evolved various genetic 
and molecular mechanisms to regulate cell death $[5,6]$. However, some of the molecular pathways are conserved between these two kingdoms [6-8], and some homologs of animal apoptotic genes are present also in plant genomes [9].

The best described mammalian apoptotic proteins belong to the Bcl-2 family [10,11]. The Bcl-2family contains both pro- and antiapoptotic regulators that possess Bcl-2 Homology (BH) domains $[10,11]$. One of the proapoptotic proteins from this family is Bcl-2-associated X (Bax) protein [12]. Activation of the Bax protein is a result of a highly regulated multistep process and leads to its translocation from the cytoplasm to the mitochondrial outer membrane (MOM) [13]. The location of the Bax protein in MOM allows the outflow of soluble proteins, including cytochrome C, from the mitochondria to cytosol, where they activate caspases, which further leads to apoptosis initialization $[11,14,15]$. The Bcl-2 family proteins are absent in yeasts and plants [9]. However, when the gene encoding mammalian Bax is artificially expressed in plants or yeast, it results in cell death [7,8,16,17]. Similarly to animal cells, the Bax protein, introduced to plant cells, is located in the mitochondrial membrane [8,17], and its transmembrane domain is necessary for lethal effect [8]. It was found that Bax-induced plant cell death in Nicotiana benthamiana is similar to the hypersensitive response (HR). The Bax-promoted cell death phenotype in Nicotiana benthamiana strongly resembled the HR phenotype induced in wildtype plants by tobacco mosaic virus. It was also shown that, during Bax-induced plant cell death, there is an accumulation of PATHOGENESIS-RELATED PROTEIN 1 (PR1) [8]. Although the proteins belonging to the Bcl-2 family are absent in plants, a homologue of Bax Inhibitor-1 (BI-1) was found in Arabidopsis thaliana [18]. BI-1 is an attenuator of cell death progression, induced by both biotic and abiotic stress. Arabidopsis thaliana atbi1-1 and atbi1-2 mutants are more susceptible to pathogens and heat stress than the wildtype [19]. Moreover, it was found that the BI-1 expression level was upregulated in response to the abovementioned factors in wildtype plants [19]. Overexpression of BI-1 resulted in reversion of the runway cell death phenotype in the lesion simulating disease 1 (lsd1-1) mutant [20], probably by its role in membrane stabilization and in deregulation of $\mathrm{Ca}^{2+}$ flux in the endoplasmic reticulum and chloroplast retrograde signalling during stress [21,22]. In Arabidopsis plants expressing Bax gene under a dexamethasone (DEX)-inducible promoter, the addition of DEX to the growth medium was sufficient to evoke cell death $[7,23]$. Interestingly, plants expressing both Bax and BI-1 survived and could continue to grow in a medium containing DEX [7], but they demonstrated no differences in PR1 mRNA accumulation level in comparison to Bax-expressing plants [7]. Moreover, Bax-induced plant cell death turned out to be reactive oxygen species (ROS)-dependent [17]. It was shown that the enhancement of ROS metabolism/decomposition by overexpressing NUCLEOSIDE DIPHOSPHATE KINASE 2 (NDPK2) or by strong antioxidant treatment resulted in partial cell death inhibition in Bax-expressing plants [17].

In the context of Bax-induced deregulation of plant cell death, the ENHANCED DISEASE SUSCEPTIBILITY 1 (EDS1) protein seems to be interesting. EDS1 together with its interacting partner, PHYTOALEXIN DEFICIENT 4 (PAD4), was described as a crucial regulator of salicylic acid (SA)-dependent defence response to biotic stresses [24,25] and as an HR regulator functioning upstream of SA-dependent PR1 mRNA accumulation [26]. Later on, it was demonstrated that SA- and EDS1-dependent HRs in plants are also regulated by chloroplast retrograde signalling depending on non-photochemical quenching (NPQ), the redox status of the plastoquinone pool and photooxidative ROS burst, and ethylene accumulation [22]. Moreover, it was shown that EDS1 is important in response to various abiotic stress [20,27-29]. Therefore, EDS1 is now considered a nonspecific, stress-related protein [22]. Both EDS1 and PAD4 exhibit homology to eukaryotic acyl lipases, and the EDS1-PAD4 complex is required for SA, ethylene, and ROS accumulation [26,30,31]. EDS1 forms dimers also with SENESCENCE-ASSOCIATED GENE 101 (SAG101) and LESION SIMULATING DISEASE 1 (LSD1) [31-35]. It was shown that EDS1 is mostly present in the cytoplasm while the EDS1-LSD1 and EDS1-PAD4 dimers are present both in the cytoplasm and nucleus [31,32,35]. The nucleus-cytoplasm ratio of EDS1 seems to be very important in plant immunity [35]. It was postulated that EDS1 together with LSD1 and PAD4 constitute a molecular hub which conditionally regulates signal 
transduction pathways, hormonal homeostasis, cell death, and acclamatory and defence responses in Arabidopsis $[21,22,36]$.

In the current study, we wanted to test if the mammalian Bax can deregulate the EDS1-dependent cell death mechanism $[21,22,36]$. Therefore, we crossed the eds1 mutant with the transgenic plants harbouring the Bax construct under a DEX-induced promoter. We showed that Bax-induced HR-like response (cell death) and growth arrest can be almost completely attenuated in the eds1 mutant background. Our result also suggests that mammalian Bax destabilizes organelle membranes in plants like it does in animals during cell death induction. Moreover, ROS and hormonal burst, normally induced in wildtype plants (with functional EDS1) are required for HR-like cell death induction in Arabidopsis expressing mammalian Bax. Our results suggest that various molecular elements of cell death mechanisms in plants and animals are compatible and, therefore, could evolve before separation of these two kingdoms.

\section{Materials and Methods}

\subsection{Plant Material and Growth Conditions}

Arabidopsis thaliana eds1 mutant plants harbouring Bax under the control of the dexamethasone (DEX)-induced promoter [7] were used in this study together with Columbia-0 (Col-0) plants. Seeds of the Bax line were a kind gift of Prof. Maki Kawai-Yamada. The eds1/Bax line was obtained in our laboratory by crossing. Homozygosity of the F3 generation was checked on Murashige-Skoog medium containing hygromycin $\left(20 \mu \mathrm{g} \mathrm{mL}^{-1}\right)$ and using real-time qPCR (Figure S1A,B). Plants where grown in the growing chamber under the following conditions: $8 / 16 \mathrm{~h}$ photoperiod, photosynthetic photon flux density (PPFD) of $130 \mu \mathrm{mol} \mathrm{m}^{-2} \mathrm{~s}^{-2}$, air humidity $60 \%$, and temperature $20 / 18^{\circ} \mathrm{C}$ day/night.

\subsection{Induction of the Bax Gene}

The Arabidopsis Bax-expressing line and eds1/Bax plants possess the open reading frame (ORF) of the mouse Bax gene under the dexamethasone (DEX)-inducible promoter in the vector pTA7002. During the fourth week of growth, plants were sprayed with $1 \mathrm{mM} \mathrm{DEX}$ solution or with the control solution ( $2 \mathrm{~mL} 96 \%$ ethanol $+48 \mathrm{~mL}$ tap water) three times in one-day intervals. All measurements were made two days after the last spray application.

\subsection{Biometric Measurements}

The dry mass was weighed using a laboratory scale (Sartorius Lab Instruments GmbH \& Co. KG, Göttingen, Germany). The rosette area was measured using the Fluor Cam 800 MF PSI device (PSI Photon Systems Instruments, Brno, Czech Republic).

\subsection{Relative Electrolyte Leakage}

Each Arabidopsis rosette was decapitated and placed in a 50-mL falcon tube filled with $30 \mathrm{~mL}$ of Milli-Q water (Merck Millipore, Darmstadt, Germany). Immediately after rosette submergence, the electrolyte leakage was measured (T0) with a conductance meter (Xylem Analytics Germany Sales GmbH \& Co. KG WTW, Weilheim, Germany). After $1 \mathrm{~h}$, the electrolyte leakage was measured again (T1). Then, in order to obtain complete ion leakage, the falcon tubes were frozen in $-80^{\circ} \mathrm{C}$ for $24 \mathrm{~h}$. After thawing, electrolyte leakage was measured again (T2). The relative electrolyte leakage was calculated as a ratio between the $\mathrm{T} 1-\mathrm{T} 0$ value and $\mathrm{T} 2$ value. The relative electrolyte leakage was expressed as a percent of total electrolyte leakage.

\subsection{Trypan Blue Staining}

Prior to measurements, the leaf discs were cut from the seventh leaf from at least five different plants per genotype. Discs were submerged in a staining solution $(0.016 \%$ trypan blue, $8 \%$ phenol, $8 \%$ glycerol, $8 \%$ lactic acid, and $65 \%$ ethanol) and incubated in $100{ }^{\circ} \mathrm{C}$ for $3 \mathrm{~min}$. The samples were 
then incubated overnight in room temperature. Next, the samples were decolorized in $6 \mathrm{M}$ chloral hydrate solution. Dead cells (coloured with blue) were observed, and the pictures were taken using Leica M165-FC fluorescent stereo microscope (Leica Microsystems, Wetzlar, Germany).

\subsection{RNA Isolation, cDNA Synthesis, and Quantitative Real-Time PCR}

Rosettes were frozen in liquid nitrogen in three biological replicates, each containing 8-12 plants. About $100 \mathrm{mg}$ of tissue was weighed and subjected to RNA isolation using Spectrum ${ }^{\mathrm{TM}}$ Plant Total RNA Kit (Sigma Aldrich, St. Louis, MO, USA). The obtained RNA was purified from residual DNA with the Ambion Turbo DNAse kit (Thermo Fisher Scientific, Waltham, MA, USA) according to the manufacturers' protocol. The concentration of RNA was measured using a UV-Vis spectrophotometer NanoDrop ${ }^{\mathrm{TM}}$ (Thermo Fisher Scientific, Waltham, MA, USA), and the RNA was diluted in order to obtain the same concentration in all tubes. cDNA was synthesized on $2 \mu \mathrm{g}$ of total RNA using a High-Capacity cDNA Reverse Transcription Kit (Thermo Fisher Scientific, Waltham, MA, USA). qPCRs were performed in three technical repetitions for each of the three biological replicates using the Power SYBR Green PCR Master Mix and the ABI 7500 Fast Real-Time PCR System (Thermo Fisher Scientific, Waltham, MA, USA). Two reference genes were used, according to the RefGenes tool incorporated in Genevestigator [37], 5-FORMYLTETRAHYDROFOLATE CYCLOLIGASE (5-FCL, AT5G13050), and PROTEIN PHOSPHATASE 2A SUBUNIT A2 (PP2AA2, AT3G25800). All primers used in this work are listed in Table S1. Specificity of the amplified PCR products was verified by melting curve analysis. Reaction efficiency was calculated using LinRegPCR [38]. The statistical significance of differences in all tested gene expressions among tested lines was calculated using REST2009 [39].

\subsection{Anatomic and Ultrastructural Analysis}

From each tested genotype, the seventh leaf was dissected in 3 biological replicates, fixed in $2 \%(v / v)$ glutaraldehyde (Sigma Aldrich, St. Louis, MO, USA) and 2\% (w/v) paraformaldehyde (Sigma Aldrich, St. Louis, MO, USA) in 50 mM sodium cacodylate buffer (pH 7.2) (Sigma Aldrich, St. Louis, MO, USA) for $2 \mathrm{~h}$. Afterwards, leaves were washed three times for 10 min with $50 \mathrm{mM}$ cacodylic buffer and embedded in epoxy resin, as described previously [40]. Leaf segments were sectioned on a Leica RM2165 microtome (Leica Microsystems, Wetzlar, Germany) into 3- $\mu$ m thick sections that were collected on glass slides, stained with $1 \%(w / v)$ aqueous solution of crystal violet dye (Sigma-Aldrich, St. Louis, MO, USA) and examined in an Olympus AX70 "Provis" light microscope (Olympus, Tokyo, Japan) equipped with an Olympus DP50 digital camera (Olympus, Tokyo, Japan). At select places, ultrathin sections ( $90 \mathrm{~nm}$ thick) were taken for transmission electron microscopy with a Leica UCT ultramicrotome (Leica Microsystems, Wetzlar, Germany). Ultrathin sections were stained with saturated solution of uranyl acetate (Sigma Aldrich, St. Louis, MO, USA) followed by incubation in lead citrate (Sigma Aldrich, St. Louis, MO, USA) and examined in an FEI 268D "Morgagni" transmission electron microscope (FEI Company, Hillsboro, OR, USA) equipped with an Olympus-SIS "Morada" digital camera (Olympus, Tokyo, Japan). Collected digital microscopic images were processed for similar contrast and brightness with Adobe Photoshop software. Samples were collected in three independent experiments.

\subsection{Protein Extraction}

Protein extracts were prepared as previously described [41]. Briefly, rosettes were grinded in a mortar with an ice-cold extraction buffer containing $50 \mathrm{mM}$ potassium phosphate buffer ( $\mathrm{pH}$ 7.0), $2 \mathrm{mM}$ 2-mercaptoethanol, $0.1 \mathrm{mM}$ ethylenediaminetetraacetic acid (EDTA), 0.5\% (v/v) Triton X-100, $2 \%(w / v)$ polyvinylpyrrolidone, and $1 \mathrm{mM}$ phenylmethylsulfonyl fluoride (PMSF). Homogenates were incubated on ice for $20 \mathrm{~min}$ and centrifuged $\left(4^{\circ} \mathrm{C}, 20 \mathrm{~min}\right.$, and 16,000 g). Obtained supernatants were used to determine total soluble protein content and processed further to measure antioxidant enzyme activities. 


\subsection{Total Soluble Protein Content}

Measurements were conducted using a Coomassie Brilliant Blue G-250 stain according to [42], with bovine serum albumin as a protein standard. The total soluble protein content was expressed in mg per gram of fresh weight (FW).

\subsection{Measurements of Antioxidant Enzyme Activity}

Superoxide dismutase (SOD) activity was measured according to the method described before [43]. An assay buffer was prepared by mixing equal volumes of $67 \mathrm{mM} \mathrm{K} / \mathrm{Na}$ phosphate buffer ( $\mathrm{pH} 7.8$ ) and $25 \mathrm{mM}$ EDTA. The $\mathrm{pH}$ value of this solution was adjusted to 10 by tetramethylethylenediamine (TEMED). Then, $1 \mathrm{~mL}$ of the assay buffer was added to $0.1 \mathrm{~mL}$ of the supernatant (previously diluted with Milli-Q water, 1:100). The SOD enzymatic assay was initiated by the addition of $0.1 \mathrm{~mL}$ of $2.5 \mu \mathrm{M}$ quercetin in dimethyl sulfoxide (DMSO). The absorbance of samples at $406 \mathrm{~nm}$ was recorded immediately and again after $20 \mathrm{~min}$. SOD activity was expressed in arbitrary units (the amount of SOD that inhibits superoxide-driven oxidation of quercetin by $50 \%$ ) per gram of FW.

\subsection{1. $\mathrm{H}_{2} \mathrm{O}_{2}$ Measurement and DAB Staining}

The $\mathrm{H}_{2} \mathrm{O}_{2}$ level and DAB (3,3'-diaminobenzidine) staining was measured/performed as described before [20,44].

\subsection{Chlorophyll a Fluorescence Measurements}

The pulse amplitude-modulated method of chlorophyll $a$ (chl $a$ ) fluorescence measurement implemented into a FluorCam 800 MF PSI device (Photon Systems Instruments, Brno, Czech Republic) was used as an indicator of the activity of photosystem II (PSII). Eighteen to twenty-two Arabidopsis thaliana plants were used for measurement for each genotype for each treatment (+mock/+DEX). Plants used for PSII activity measurement were grown under the conditions described above and were adapted in the dark $30 \mathrm{~min}$ before measurement. The following parameters were measured: quantum yield of PSII photochemistry in the dark-adapted state ( $\mathrm{Fv} / \mathrm{Fm})$, maximum quantum efficiency of PSII photochemistry $\left(\mathrm{Fv}^{\prime} / \mathrm{Fm}^{\prime}\right)$, effective quantum yield of PSII photochemistry ( $\phi$ PSII), and non-photochemical quenching (NPQ).

\section{Results}

\subsection{Artificially Bax-Induced HR-Like Cell Death Propagation and Growth Inhibition Depend on EDS1}

It is known that Bax can induce the cell death mechanism in plants, and our goal was to check if EDS1-dependent signalling is involved in this process. Therefore, the eds1 mutant was crossed with plant harbouring the Bax gene under the DEX-inducible promoter (Figure S1 and [7]). The obtained eds1/Bax line was widely tested in the context of plant morphology and cell death. Even among the plants treated with the mock solution, we found some differences in growth. The Bax plants (+mock) were significantly smaller (Figure 1A,B) and had reduced biomass (Figure 1C) when compared to the mock-treated wildtype plants and other mutants used in this study. Among plants treated witch DEX solution, we found even more pronounced differences. The Bax (+DEX) plants were significantly smaller, and their biomass was lower than the wildtype and eds1 mutant (+DEX) (Figure 1A-C), while eds1/Bax (+DEX) plants did not differ from Col-0 (Figure 1A-C). This effect was reproducible and observed in all individual plants (Figure S2). Moreover, we found significant differences in cell death among the tested genotypes. Within mock-treated plants, Bax line did not demonstrate significant differences in ion leakage (Figure 2A). However, the eds1 mutant and eds1/Bax line were proven to have lower ion leakage compared to the wildtype (Figure 2A). Among plants treated with DEX, we found notable changes in cell death level. The DEX-treated wildtype and eds1 mutant did not exhibit higher ion leakage, while in Bax plants + DEX, we found two times higher ion leakage 
when compared to the wildtype + DEX. Ion leakage in eds1/Bax + DEX plants was slightly increased in comparison to the wildtype + DEX but was clearly lower than in Bax + DEX (Figure 2A). Using trypan blue staining, we found very few dead cells among plants treated with the mock solution (Figure 2B). Similarly, in the DEX-treated wildtype and eds1 mutant, the number of dead cells was small (Figure 2B). However, in Bax + DEX plants, we found a relatively high number of dead cells (Figure 2B), while cell death was evidently less pronounced in eds1/Bax + DEX plants when compared to Bax line (Figure 2B). Here, we clearly show that EDS1-dependent molecular cell death mechanisms can be deregulated by animal Bax since Bax-dependent growth inhibition and Bax-induced HR-like cell death propagation were reverted in the eds1 null mutant background.

A)

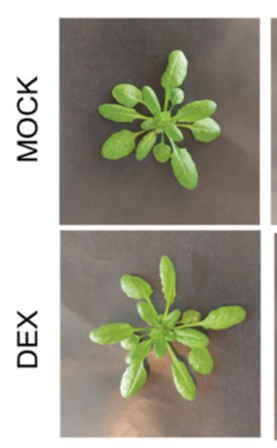

Col-0

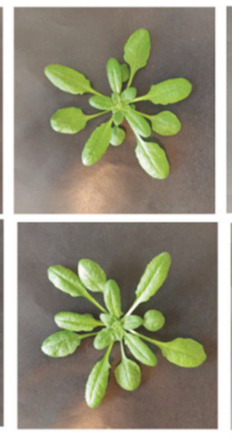

eds1

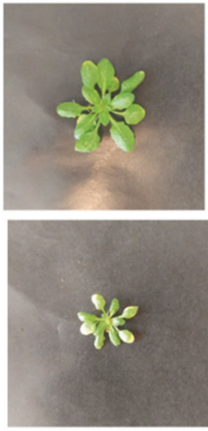

Bax

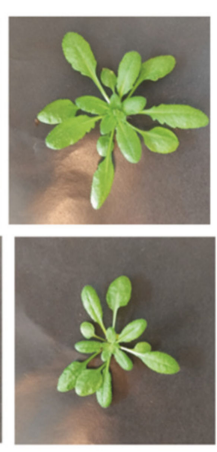

eds1/Bax
B)

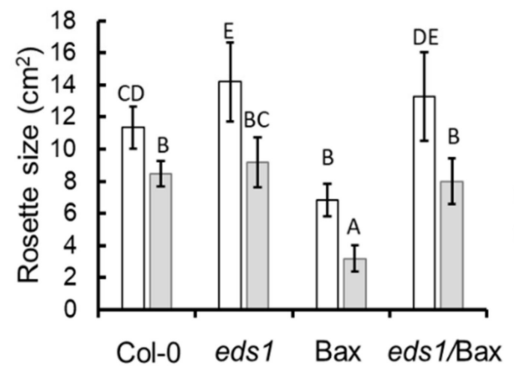

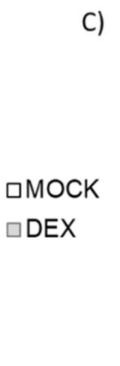

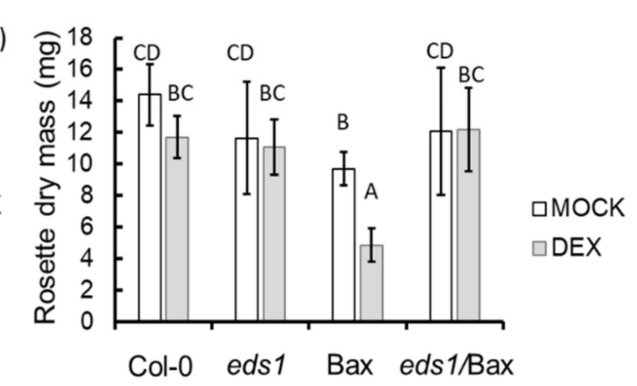

Figure 1. Plant phenotype (A), rosette size (B), and biomass (C) in the wildtype, ENHANCED DISEASE SUSCEPTIBILITY 1 (eds1) mutants, and Bax and eds1/Bax lines (+mock/+DEX (dexamethasone)): within a subgraph, values sharing common labels (letters) are not significantly different from each other $(p>0.001)(n=8-12)$.

A)

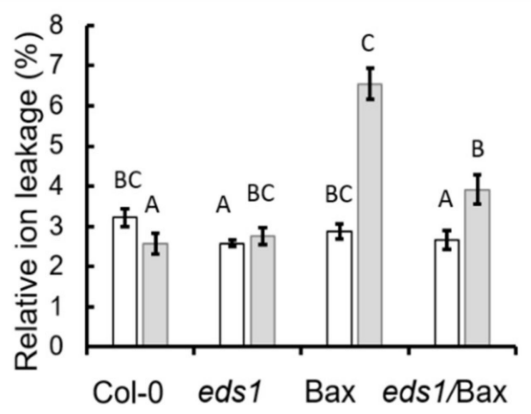

B)

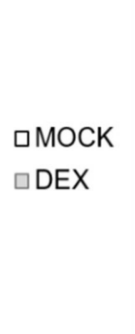

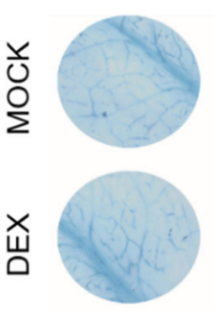

Col-0

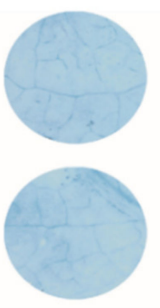

eds1

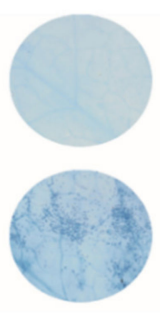

$\mathrm{Bax}$

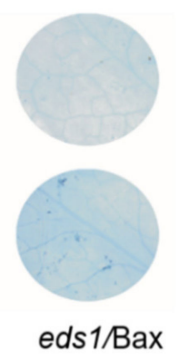

$5 \mathrm{~mm}$

Figure 2. Cell death in the wild type, eds1 mutants, and Bax and eds1/Bax lines (+mock/+DEX) shown as (A) ion leakage and (B) trypan blue staining of dead cells: within a subgraph, values sharing common labels (letters) are not significantly different from each other $(p>0.001)(n=10-18)$. 
3.2. EDS1-Dependent Regulation of Antioxidant System and ROS Metabolism is Required for Bax-Induced HR-Like Cell Death

It is well known that ROS are crucial molecules in cell death signalling [45,46], and it was shown many times that EDS1 is an important ROS homeostasis regulator in plants $[20,22,27,47]$. Moreover, it was found that the expression of mammalian BAX in plants leads to higher ROS production [17]. Therefore, we decided to perform extensive analyses of ROS homeostasis and the antioxidant system. In the group of plants treated with the mock solution, we found $25 \%$ lower $\mathrm{H}_{2} \mathrm{O}_{2}$ content in eds 1 and eds 1 /Bax plants and $15 \%$ higher $\mathrm{H}_{2} \mathrm{O}_{2}$ content in Bax plants in comparison to the wild type (Figure 3A). In the group of plants treated with the DEX solution, we found even more pronounced differences. Similar to mock-treated plants, DEX-treated eds1 proved to have lower $\mathrm{H}_{2} \mathrm{O}_{2}$ foliar concentration compared to the wildtype. The Bax + DEX plants exhibited the highest $\mathrm{H}_{2} \mathrm{O}_{2}$ content, whereas the level of $\mathrm{H}_{2} \mathrm{O}_{2}$ in eds1/Bax + DEX did not differ from the wildtype (Figure 3A). Histochemical $\mathrm{H}_{2} \mathrm{O}_{2}$ visualization using 3,3'-diaminobenzidine (DAB) confirmed the above results (Figure 3B). Moreover, the differences in $\mathrm{H}_{2} \mathrm{O}_{2}$ content were accompanied by deregulated activity of superoxide dismutase (SOD). In mock-treated plants, only the eds1/Bax line demonstrated a significantly higher activity of SOD in relation to the wild type. Within DEX-treated plants, the highest SOD activity was found in eds1 and eds1/Bax, while SOD activity in Bax + DEX plants did not differ from wildtype plants (Figure 3C). In addition, significant differences in the expression level of ROS marker genes (Table S2) [48,49] have been found (Figure 4A-C). TRYPSIN INHIBITOR PROTEIN 1 (TL1, AT2G43510) was proposed as a marker gene for many ROS forms and DMR6-LIKE OXYGENASE 1 (DLO1, AT4G10500) is marker gene for $\mathrm{H}_{2} \mathrm{O}_{2}$, while beta-glucosidase BLG23 (AT3G09260) and BIFUNCTIONAL INHIBITOR/LIPID-TRANSFER PROTEIN (BIF, AT4G22490) are markers genes for superoxide $\left(\mathrm{O}_{2}^{-}\right)$[48]. Moreover, BON1-associated protein 1 (BAP1, AT3G61190) [50] and AAA-ATPase 1 (AAA-ATPase1, AT3G28580) [51] were used as specific singlet oxygen $\left({ }^{1} \mathrm{O}_{2}\right)$ marker genes. Among the plants treated with the mock solution, only the Bax line demonstrated significantly higher TL1 expression level than the wildtype. In the group of plants treated with the DEX solution, eds1 mutant plants showed significantly lower TL1 expression level, while Bax plants exhibited the highest expression level of TL1. Importantly, the level of TL1 expression in eds1/Bax did not differ from the wildtype (Figure 4A). The expression level of DLO1 in wildtype, eds1, and eds1/Bax plants was very low both under mock and DEX treatment. Meanwhile, DLO1 was six times more expressed in the Bax line treated with the mock solution and even higher (more than ten times) in the Bax + DEX line when compared to the wildtype (Figure 4B). Within mock-treated plants, the level of BLG23 expression was significantly induced in the eds1 mutant and Bax line in relation to Col-0. In Bax plants treated with the DEX solution, BLG23 expression level was two times higher than in the wildtype (Figure 4C). However, the mutation in eds1 reverted the BLG23-induced expression in Bax + DEX since there was no significant difference in BLG23 expression between the eds1/Bax + DEX line and Col-0 + DEX. We did not find any changes in BIF expression level among the wildtype, eds1, and eds1/Bax lines for non-treated or DEX-treated samples. However, a higher expression level of BIF was found in Bax plants both treated with mock and DEX (Figure 4D). Col-0, eds1, and eds1/Bax regardless of the treatment did not exhibit changed expression in specific markers genes for ${ }^{1} \mathrm{O}_{2}$, while Bax plants exhibited very high expression of BAP1 and AAA-ATPase1 in both mock- and DEX-treated samples (Figure S3A,B). Our results clearly prove that EDS1 is necessary and is a crucial ROS homeostasis regulator during Bax-induced plant cell death. 
A)

B)
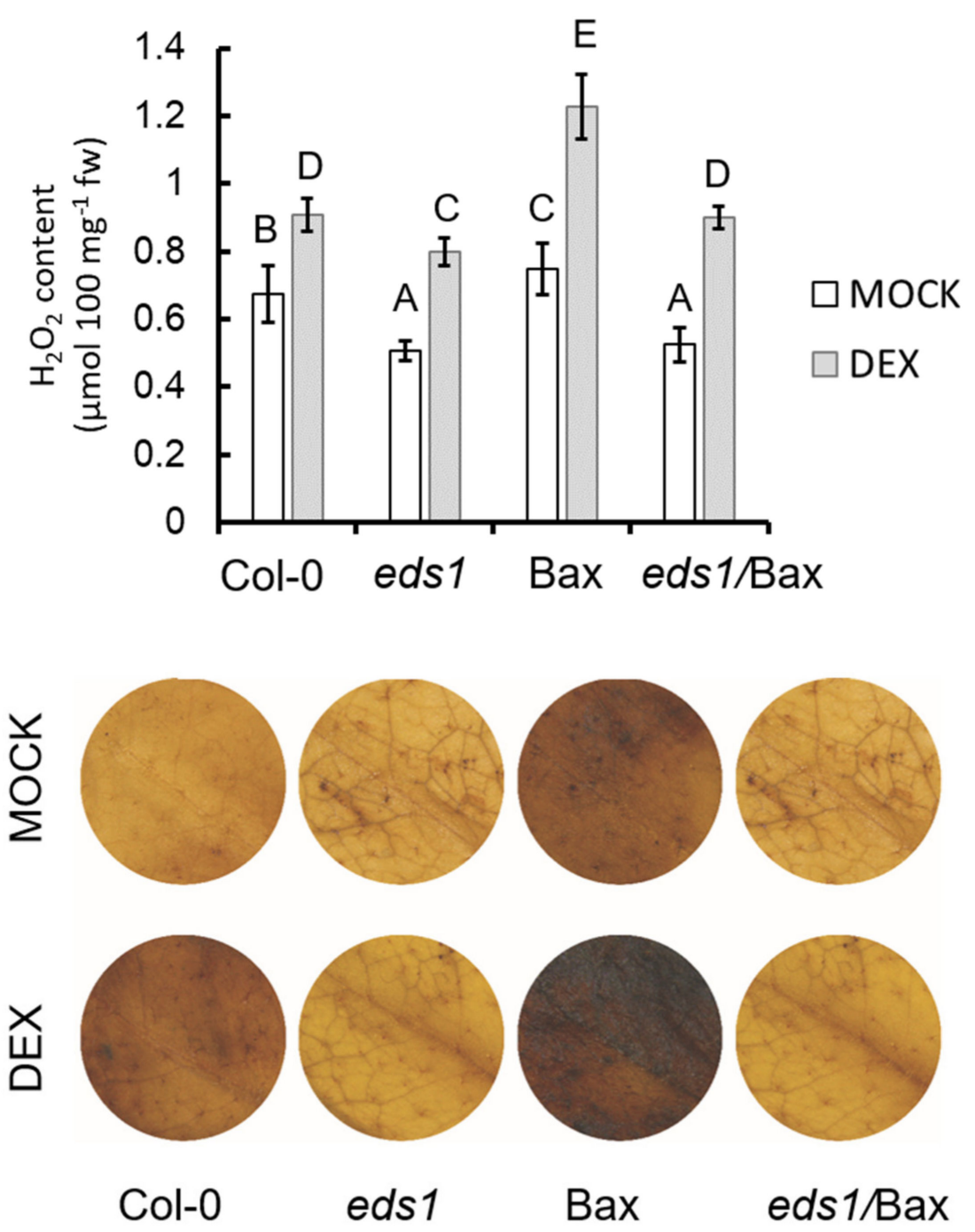

C)

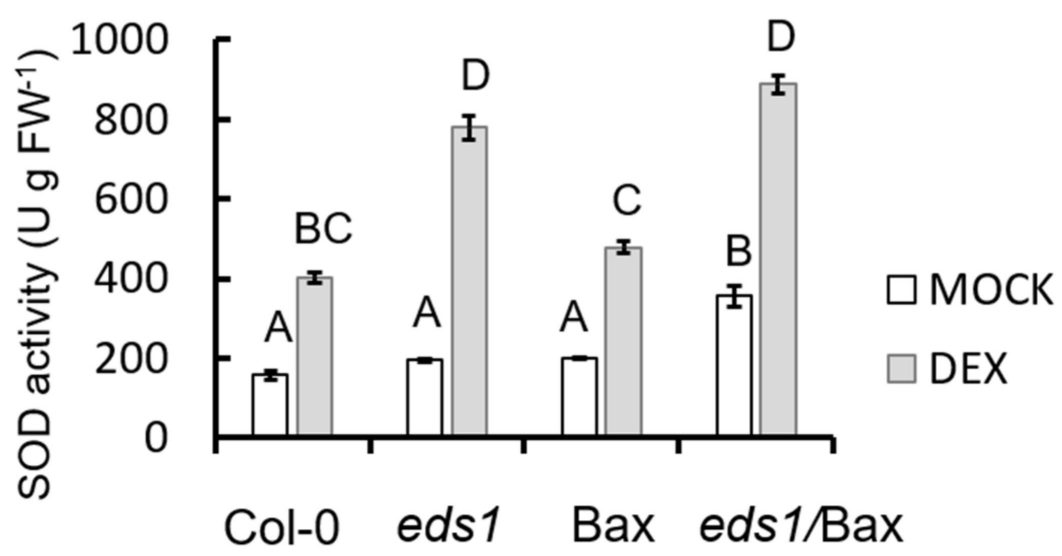

Figure 3. Content of $\mathrm{H}_{2} \mathrm{O}_{2}$ and superoxide dismutase (SOD) activity in the wildtype, eds1 mutant, and Bax and eds1/Bax lines (+mock/+DEX): (A) $\mathrm{H}_{2} \mathrm{O}_{2}$ content in leaves, $($ B $) \mathrm{H}_{2} \mathrm{O}_{2}$ visualization using $\operatorname{DAB}\left(3,3^{\prime}\right.$-diaminobenzidine) staining, and (C) activity of SOD. Within a subgraph, values sharing common labels (letters) are not significantly different from each other $(p>0.001)(n=10-12)$. 
A)

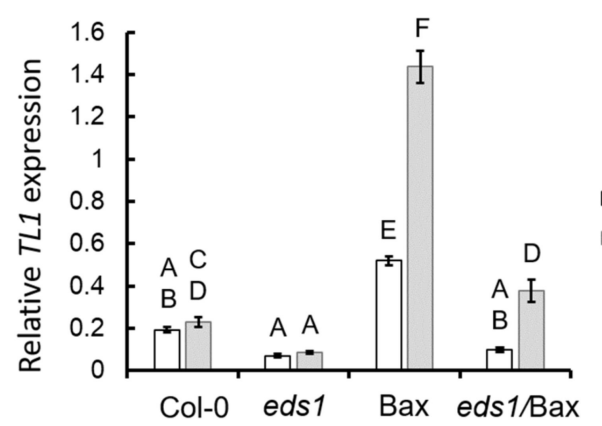

C)

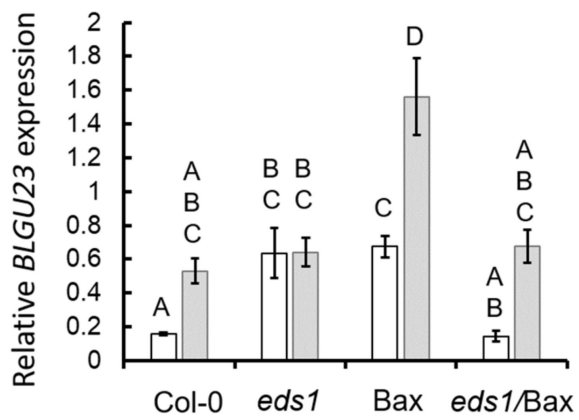

B)

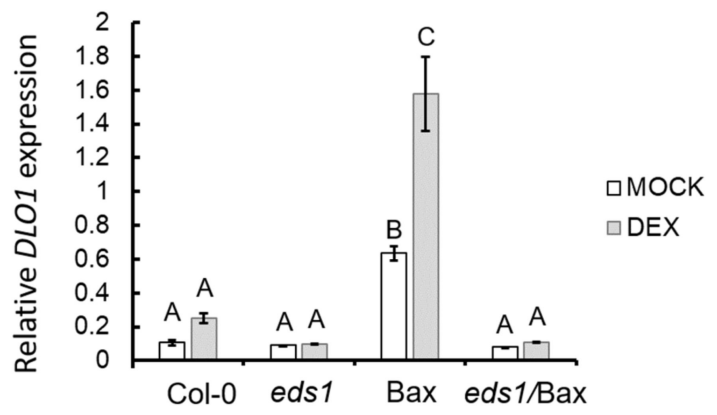

D)

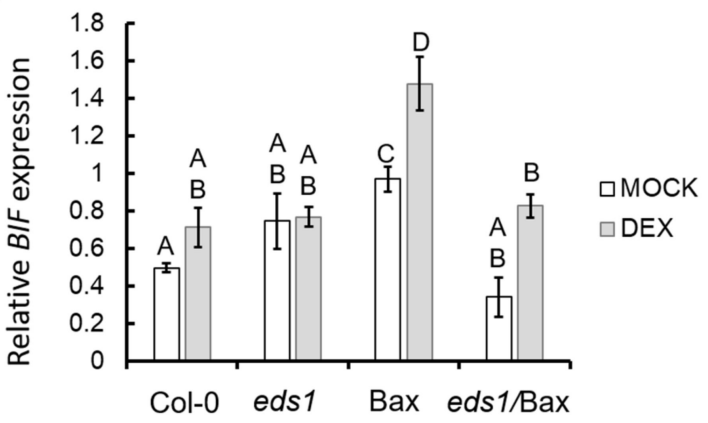

Figure 4. Relative expression level of marker genes of different reactive oxygen species (ROS) forms in the wild type, eds1 mutant, and Bax and eds1/Bax lines (+mock/+DEX): marker gene for (A) many ROS forms (TL1), (B) hydrogen peroxide $\left(\mathrm{H}_{2} \mathrm{O}_{2}\right)\left(\right.$ DLO1), and superoxide $\left(\mathrm{O}_{2}^{-}\right)$(C) BLGU23 and (D) BIF). Within a subgraph, conditions sharing common labels (letters) are not significantly different from each other $(p>0.001)(n=8-10)$.

\subsection{EDS1 is Essential for the Induction of Hypersensitive Response and Senescence During Bax-Induced Plant} Cell Death

EDS1 has been shown to positively regulate the expression level of HR marker genes, and the eds1 mutant is unable to induce the expression of PATHOGENESIS-RELATED (PR) genes [52,53]. On the other hand, the overexpression of EDS1 leads to higher PR genes expression [54]. Therefore, in the next step, we wanted to know if EDS1-dependent PR gene expression is involved in Bax-induced plant cell death. PR1 (AT2G14610), PR2 (AT3G57260), PR5 (AT1G75040), HIN1-LIKE 8 (NHL8, AT1G32340), and SENESCENCE-ASSOCIATED GENE 12 (SAG12, AT5G45890) [52] were used as hypersensitive response marker genes [6,8,52-54]. Among plants treated with the mock solution, the highest level of $P R$ gene expression was exhibited by the Bax line (Figure $5 \mathrm{~A}-\mathrm{C}$ ). The expression of $P R$-genes in the eds1 mutant was marginal. We also found that the eds1/Bax line demonstrated a similarly low level of all PR gene expressions to the eds1 mutant. Among plants treated with the DEX solution, we did not observe any significant changes in the expression level of PR-genes in wildtype, eds1, or eds1/Bax plants. On the contrary, the expression level of PR1, PR2, and PR5 was significantly upregulated in Bax + DEX plants (Figure 5A-C). A similar level of NHL8 expression was found in the wildtype, eds1, and eds1/Bax plants regardless of treatment. However, in the DEX-treated Bax line, the level of NHL8 expression was upregulated in comparison to the wildtype (Figure S4A). The expression level of a senescence marker gene, $S A G 12$ [55], was significantly elevated in the Bax line, irrespective of mock or DEX treatment (Figure S4B). On the contrary, the SAG12 expression level in both the mock- and DEX-treated wildtypes, in eds1, and in eds1/Bax plants was marginal (Figure S4B). These results clearly show that, during Bax-induced plant cell death, the HR is activated and that EDS1 is necessary for this process. 
A)

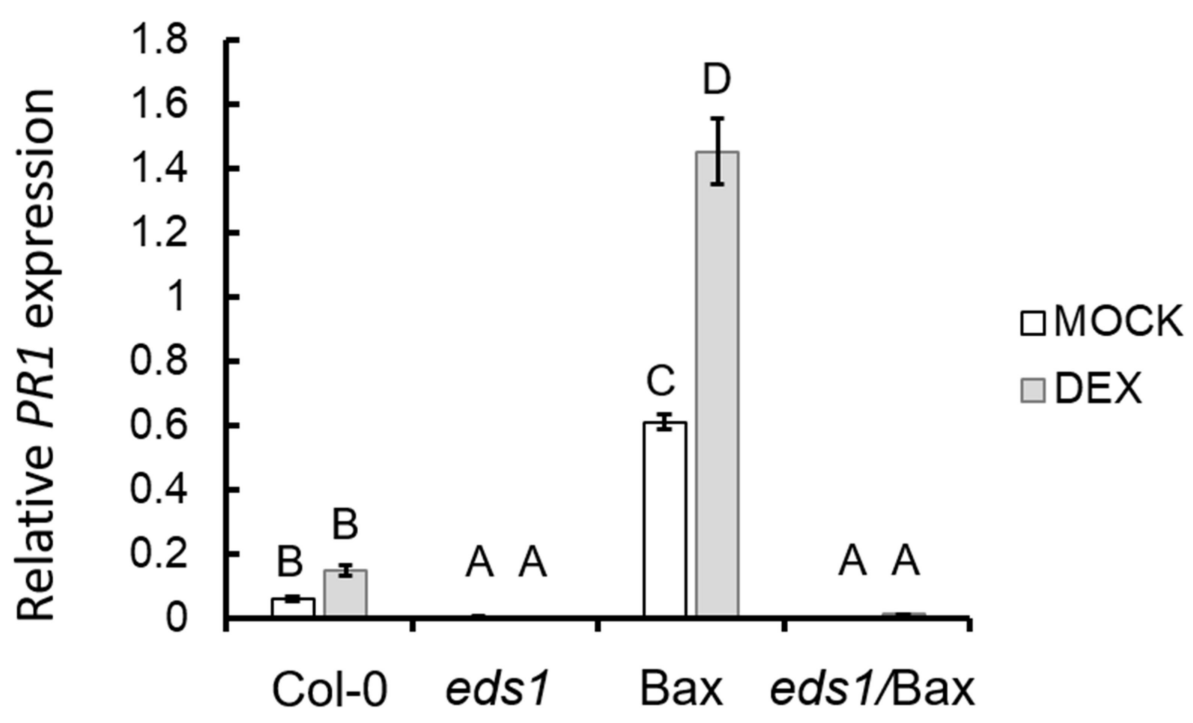

B)

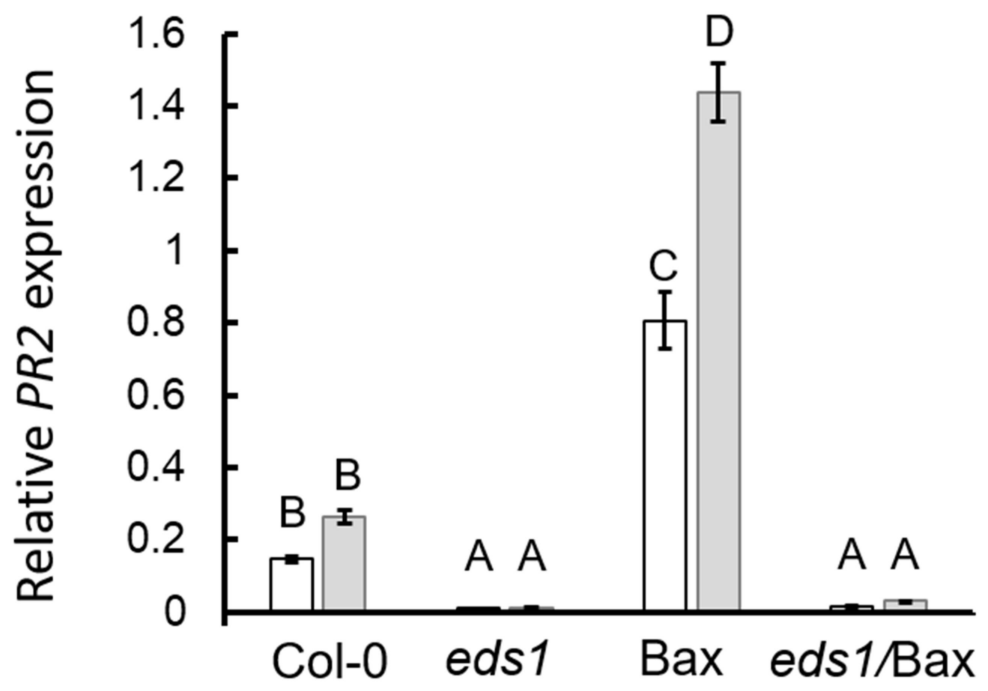

C)

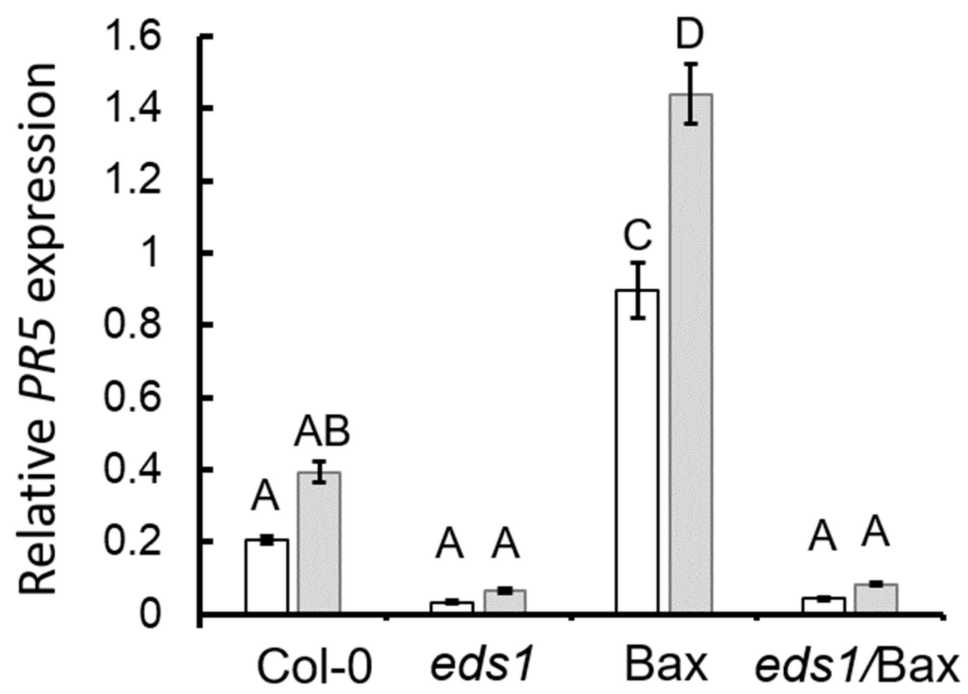

Figure 5. Relative expression levels of hypersensitive response (HR) marker genes in the wildtype, eds1 mutant, and Bax and eds1/Bax lines: (A) PR1, (B) PR2, and (C) PR5. Within a subgraph, values sharing common labels (letters) are not significantly different from each other $(p>0.001)(n=6)$. 


\subsection{Arabidopsis thaliana Type I Metacaspases Seem to Be Involved in Bax-Induced Plant Cell Death}

In mammalian cells, caspase activity is an essential step in Bax-dependent cell death [5]. True caspases have not yet been described in plants [56]; however, in plants, there are caspase-like proteins: metacaspases [57]. Therefore, we decided to check the expression level of genes encoding the two best-described metacaspases, METACASPASE 1 and 2 (MC1 and MC2). The expression level of MC1 was relatively high in all mock-treated genotypes. MC1 was slightly upregulated in the Bax line and downregulated in the eds1 mutant and eds1/Bax line; however, these changes were not statistically significant when compared to the wildtype (Figure S5A). Among plants treated with the DEX solution, we found higher $M C 1$ expression in Bax and eds1/Bax in comparison to the eds1 mutant. The expression level of MC2 was not significantly different in mock-treated eds1 and eds1/Bax plants but significantly higher in the Bax line in comparison to the wildtype. In response to the DEX treatment, we found significant upregulation of the MC2 expression level in the Bax line in relation to Col-0 + DEX. The eds1 mutant demonstrated significant downregulation of $M C 2$ expression when compared to the wildtype, and the same tendency was shown in the eds1/Bax line.

\subsection{Improved Antioxidant System and Impaired HR Result in the Mitigation of Mammalian Bax-Induced Cellular Organelle Destruction}

Among the plants treated with the mock solution, the anatomy of the leaves and the ultrastructure of leaf mesophyll cells were similar. In all tested cells, we found a central vacuole typical for mesophyll cells. Chloroplasts as well as mitochondria had typical shapes. The structure of thylakoids was not disturbed (Figure 6A). Wildtype and eds1 mutant cells treated with the DEX solution looked the same as mock-treated plants, and we did not demonstrate any disturbances (Figure 6A). However, cells of the Bax line treated with DEX were clearly damaged. We observed a clear disintegration of the membranes and we found more plastoglobules that were bigger in comparison to the wild type. Moreover, the thylakoids were clearly distended (Figure 6A,B). In eds1/Bax cells, the damage was not so clear, and those cells looked more similar to the wildtype cells than the cells of the Bax line (Figure 6A). The main aberration in eds1/Bax cells was some damage within thylakoids (Figure 6B). Interestingly, we did not observe mitochondrial damage in any of the tested genotypes or treatments. These results indicate that, during Bax-induced cell death, EDS1 is involved in the process of cellular membranes disintegration, probably by its role in ROS and hormonal homeostasis regulation.

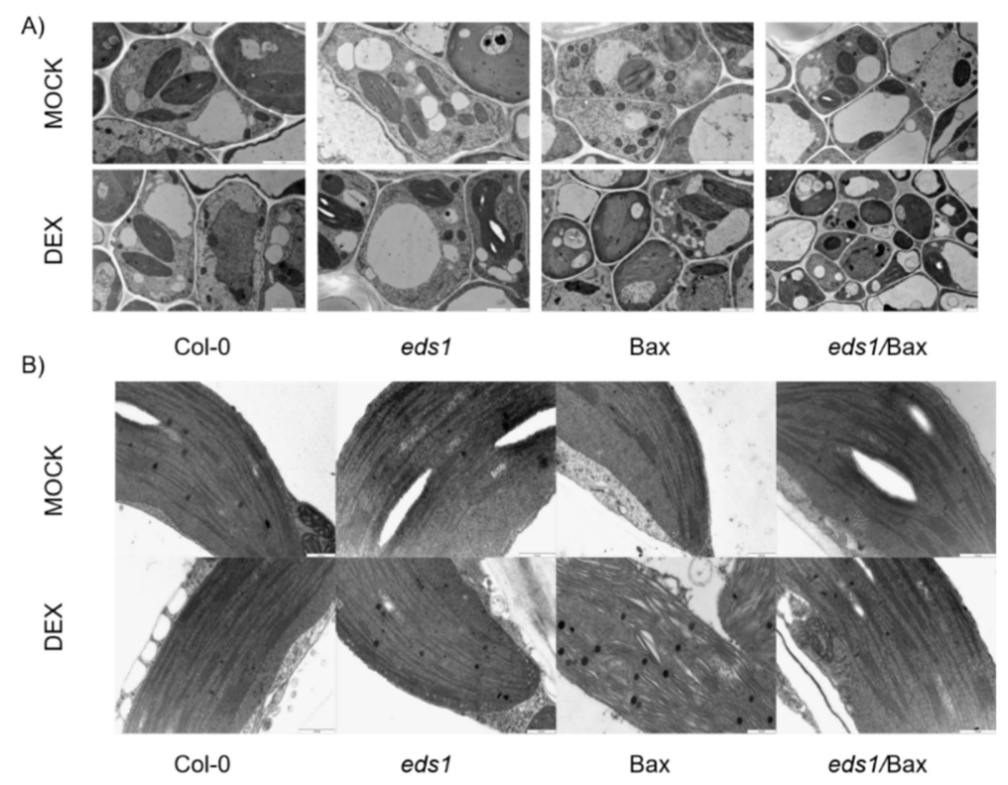

Figure 6. Transmission electron microscopy (TEM) images presenting cell architecture (A) and chloroplasts (B) in the wildtype, eds1 mutant, and Bax and eds1/Bax lines (+mock/+DEX). 


\subsection{EDS1 Does Not Significantly Affects the Efficiency of PSII During Bax-Induced Plant Cell Death}

No difference in $\mathrm{Fv} / \mathrm{Fm}$ or $\mathrm{Fv}^{\prime} / \mathrm{Fm}^{\prime}$ was found among genotypes tested in this study, regardless of treatment (Figure S6A,B). The only difference found concerned $\phi$ PSII, which was lower in the Bax line in comparison to other genotypes (Figure S6C). Interestingly, NPQ was significantly increased in the eds1/Bax line after DEX treatment, which was not observed in the Bax line (Figure S6D).

\section{Discussion}

It was suggested that direct comparison of Bax-induced plant cell death and HR-mediated cell death at the cellular level would provide valuable information concerning plant programmed cell death (PCD) and its similarity to mammalian apoptosis [17]. In this work, we confirmed previous reports indicating that mammalian Bax is able to induce cell death in plants $[8,16,18]$. So far, it was postulated that Bax-induced cell death in plants is similar to HR [8], occurs via ROS-dependent and -independent pathways [17], and is initiated by organelles destruction $[7,16]$. However, the molecular pathways and individual proteins involved in the Bax-dependent cell death pathway in plants were weakly described. Therefore, the aim of the current work was to test if EDS1, a plant-specific regulator of PCD, may be involved in Bax-induced plant cell death pathways. By crossing the eds1 mutant with the Bax-expressing line (under a DEX-inducible promoter) [7] we obtained the eds1/Bax line, which was used to examine the role of EDS1 in Bax-induced ROS accumulation, membrane destruction, HR, and finally plant cell death.

In the course of our research, we found strong cell death symptoms in plants, where Bax was induced with DEX treatment. Bax + DEX plants were significantly smaller than wildtype plants, showed yellowing of the leaves, and exhibited elevated cell death level. However, we found no differences in rosette size of the eds1/Bax + DEX line in comparison to the wild type, and these plants did not exhibit characteristic, Bax-specific yellowing. In eds1/Bax + DEX plants, we found a slightly higher level of cell death in comparison to the wild type but still a significantly lower one than in Bax + DEX plants. It was previously found that mammalian Bax-induced cell death in plants can be downregulated by BI-1 overexpression [7,58]. However, in BI-1-OE/Bax plants, the cell death phenotype was not completely reversed and $P R 1$ protein and ROS were still over-accumulated $[16,18,58]$. Those plants still exhibited reduced size, increased chlorophyll degradation, and higher cell death level $[16,58]$. Such a strong phenotype reversal in eds1/Bax plants in terms of cell death is caused by significant changes in HR, by ROS homeostasis regulation, and by changes within membranes integration, which were all previously proposed as Bax-dependent cell death features in plants $[16,17,58]$.

One pathway of Bax-induced HR occurs through ROS signalling [17]. It is known that ROS can act as HR-triggering molecules [46,59] and that $\mathrm{H}_{2} \mathrm{O}_{2}$ induces EDS1 expression [60]. In our study, we found that $\mathrm{Bax}+$ DEX plants exhibited a high $\mathrm{H}_{2} \mathrm{O}_{2}$ level in tissues and that the $\mathrm{H}_{2} \mathrm{O}_{2}$ level in eds1/Bax + DEX was significantly lower in comparison to Bax + DEX plants. Moreover, we found significant changes in the expression level of different ROS form markers. The expression of all TL1, DLO1, BLGU23, $B I F, B A P 1$, and $A A A-A T P a s e 1$ was upregulated in Bax plants in comparison to the other genotypes. Higher expression of ${ }^{1} \mathrm{O}_{2}$ marker genes could be causes by certain disturbances in photosystem II (Figure S6). Studying the ROS marker genes, we showed that, during Bax-induced plant cell death, many ROS forms can be overproduced and that EDS1 is involved in their metabolism, scavenging, or signalling [61]. Moreover, in our study, Bax + DEX plants demonstrated higher EDS1 expression, compared to the other genotypes (Figure S1). In plant cells, the Bax protein is located in MOM, similar to animal cells [16,58]. Moreover, in mammalian cells, it was found that $\mathrm{H}_{2} \mathrm{O}_{2}$ is overproduced in mitochondria during apoptosis [62]. In our study, during Bax-induced plant cell death, we observed more significant damages within chloroplasts than in mitochondria [16,58]. Chloroplast damage can lead to further ROS production because of PSII disruption, which may be indicated by the inability to increase the NPQ, observed in the Bax line [63-65]. In the eds1/Bax + DEX line, there was no EDS1 expression and lack of EDS1 inhibited HR induction also via the inhibition of ROS accumulation. EDS1 was postulated as an antioxidant system inhibitor [22], and it was found that the Arabidopsis thaliana eds1 
mutant accumulated less $\mathrm{H}_{2} \mathrm{O}_{2}$ in response to stress than the wildtype [20,47]. Moreover, lower $\mathrm{H}_{2} \mathrm{O}_{2}$ content and higher antioxidant system activity were found in EDS1-silenced transgenic poplar [66], which indicates that the role of EDS1 in ROS homeostasis is strongly preserved in higher plants.

$\mathrm{HR}$ is a plant response to a wide range of stresses, both biotic $[67,68]$ and abiotic $[69,70]$. It is a multicomponent response manifested in higher $P R$ genes expression, antimicrobial secondary metabolite accumulation, and lesion formation $[46,68]$. It was postulated that mammalian Bax-induced plant cell death is similar to HR, and it was found that the PR1 protein is over-accumulated when mammalian Bax is expressed in plants [8]. In present study, after Bax induction, we found significantly higher PR1, PR2, and PR5 gene expressions. Moreover, we found higher NHL8 and SAG12 gene expression, which are proposed as early HR and senescence marker genes, respectively [52]. EDS1 and its interacting partner, PAD4, were described as important HR regulators [32,71]. It was shown that EDS1 is crucial in HR induction in response to Botrytis cinerea [72] and that harpin-elicited hypersensitive cell death depends on EDS1 [73]. In the wildtype tomato and Arabidopsis, it was found that the expression of EDS1 is induced in response to biotic stress, which leads to higher PR1 expression [32,72], while in the Arabidopsis eds1 mutant, the PR1 gene expression is significantly lower in comparison to the wildtype [71]. Moreover, it was demonstrated that the eds1 mutation, introduced into the constitutive expressor of $P R$ genes 1 (cpr1) mutant, reverses the accumulation of PR1, PR2, and PR5 mRNAs, characteristic for cpr1 single mutant [53,73]. Likewise, it is known that HR is generally controlled by disease resistance $(\mathrm{R})$ genes $[66,68]$ and that EDS1 is required for the activity of the TIR-NBS-LRR class of R-genes [74]. It indicates that plants lacking the EDS1 protein are unable to activate the HR response $[75,76]$. In our study, we found a strong expression of $P R$ genes in Bax + DEX and lack of or minimal PR-gene expression in $e d s 1 /$ Bax plants + DEX. Moreover, in $e d s 1 / \mathrm{Bax}+\mathrm{DEX}$ plants, there was no difference in NHL8 expression level in comparison to the wildtype. These results prove that the expression of mammalian Bax in plant cells leads to HR induction and that a lack of active $\mathrm{s}$ inhibits this process.

Interestingly, Arabidopsis HR can be induced by metacaspases [77]. It is known that, in animal cells, Bax protein leads to the outflow of cytochrome $C$ from the mitochondria to the cytoplasm, leading to caspase activation, which is a signal to initiate apoptosis [11,14,15]. It cannot be excluded that a similar mechanism occurs in plants. In our study, we found slightly higher $M C 1$ expression in both the Bax + DEX and eds1/Bax + DEX plants. Proteins encoded by MC1 are a positive regulator HR, and it was shown that mutation in MC1 nearly eliminates HR in Arabidopsis [77]. This result suggests that the Bax protein is active in both Bax + DEX and eds1/Bax + DEX plants but the lack of active EDS1 protein inhibits $\mathrm{HR}$ induction. It was also found that $M C 1$ pro-cell death activity is negatively regulated by LSD1 [77]. A direct interaction between LSD1 and EDS1 was previously demonstrated [35] so we can hypothesize that EDS1 is also involved in MC1-dependent HR induction. However, based on our results, we cannot say with certainty that Bax expression in plant cell leads to metacaspase activation in a similar way as caspase activation in animal cells. To confirm this, further studies are required. In addition, we found a significantly higher MC2 expression level in Bax + DEX plants in comparison to other tested genotypes, including eds1/Bax + DEX. However, $M C 2$ is a negative regulator of cell death [75], and high expression of this gene could be linked to stress-related signalling pathways connected with Bax expression.

It was previously found that the expression of mammalian Bax in plant cells leads to organelle destruction [16,58]. In plants expressing mammalian Bax, the cytoplasmic shrinkage, chloroplast destruction, and changes in mitochondrial structures in mesophyll cells were apparent [58]. Interestingly, the disruption of chloroplasts was observed 1 to 2 days after Bax induction [16]. It indicates that chloroplast damage during Bax-induced cell death is caused by a secondary effect, most probably induced by ROS coming from mitochondria. It was found that the overexpression of BI-1 mitigates organelle destruction when mammalian Bax is expressed in plants [58], but this mechanism has not been precisely explained. It was proposed that BI-1 suppresses Bax-induced plant cell death acting downstream of oxidative burst or alternative processes lacking the involvement of ROS [17]. It is 
possible that BI-1 acts as a suppressor of the Bax-induced HR-like cell death in its early stage because it was found that $B I-1$ is upregulated in response to many stresses and that the atbi-1 mutant exhibited strong HR phenotype $[19,78]$. In our study, we found no differences between the mitochondria structure of Bax + DEX and eds1/Bax + DEX plants. However, the plasma membrane in Bax + DEX was clearly damaged, and strong changes in the thylakoids structure were found. These changes did not occur in $e d s 1 / \mathrm{Bax}+\mathrm{DEX}$ plants, and we propose that this is because of the improved antioxidant system in $e d s 1 /$ Bax plants. It could be another reason for strong reversal of the cell death phenotype and senescence symptoms in the eds1/Bax + DEX line. The senescence symptoms, such as membrane degradation, increased the number of plastoglobules and chloroplast degradation [79], which we found in Bax + DEX plants were not observed in eds1/Bax + DEX.

Based on the previous reports and results described in the current work, we propose the following model of similarities in the molecular mechanism of cell death regulation in plants and animals and the involvement of plant protein EDS1 in the propagation of mammalian Bax-induced cell death (Figure 7). It was found that the Bax protein in plant cells, similar to animal cells, is located in the mitochondrial membrane [16,80]. Its main role is to allow the outflow of cytochrome $C$ into the cytoplasm [81], but it has also been shown that Bax stimulates ROS production in mitochondria [81]. Cytoplasmic ROS causes damage to chloroplasts $[82,83]$ and contributes to higher ROS production $[84,85]$. Moreover, it was found that ROS can induce the expression of EDS1 in the nucleus ([72] and Figure S1). The EDS1 protein can support mammalian Bax-induced plant cell death in two ways. One scenario is that EDS1 acts as a negative regulator of the antioxidant system, which contributes to disturbance in ROS scavenging [22]. The second scenario is that EDS1 propagates mammalian Bax-induced plant cell by its role in HR, systemic acquired resistance (SAR), and systemic acquired acclimation (SAA) [8], which leads to cell death in Bax-expressing plants.

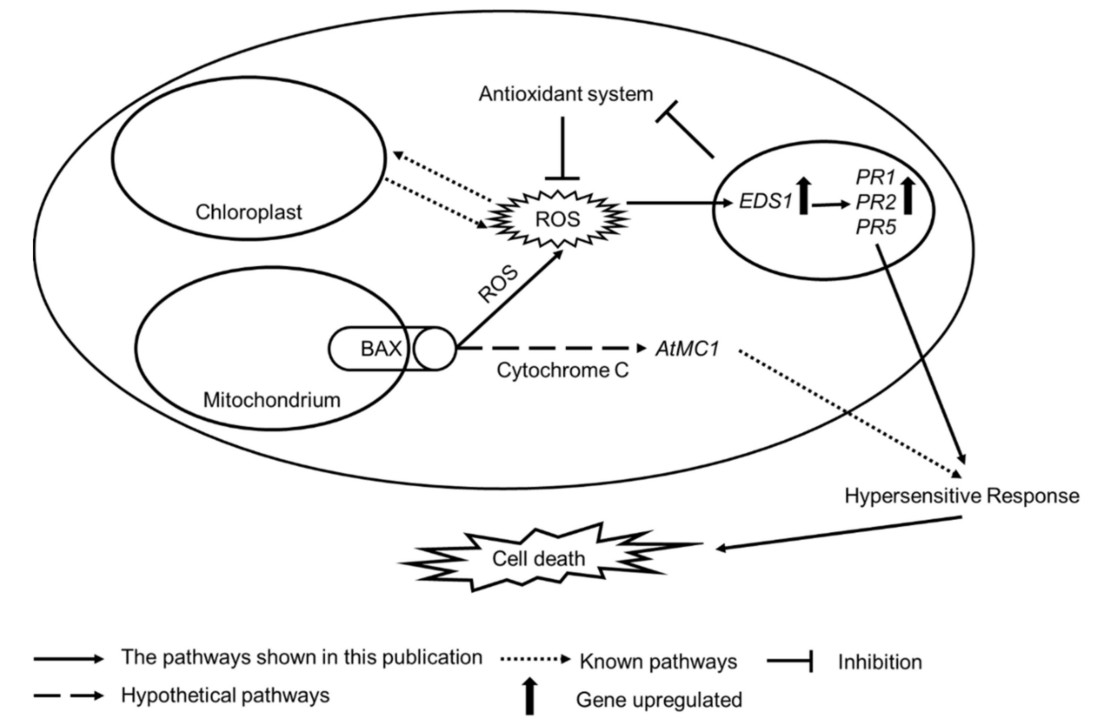

Figure 7. Proposed model of plant (EDS1) and animal (Bax) proapoptotic dependency in the cell death process in an artificial system used in this study: analogous to animal cells, the Bax protein in plant cells is located in the mitochondrial membrane [8,17]. It leads to the outflow of mitochondrial content (including ROS) to the cytoplasm. This so-called first ROS wave can act not only as a signal but also as a damaging factor to the chloroplast membranes, leading to the generation of a second ROS wave derived from chloroplasts. $\mathrm{H}_{2} \mathrm{O}_{2}$ induces EDS1 expression in the nucleus [60]. EDS1 is required for PATHOGENESIS-RELATED (PR) protein accumulation. PR proteins trigger HR and, as a consequence, cell death [32]. Moreover, EDS1 acts as a negative regulator of the antioxidant system and thus contributes to increasing ROS content in plant tissues [22]. Furthermore, expression of mammalian Bax may lead to cytochrome $C$ outflow to the cytoplasm and the activation of plant metacaspases. Some metacaspases, such as AtMC1, induce cell death. 
In this study, we demonstrate that the inability to initiate HR and improve ROS metabolism via mutation in EDS1 nearly eliminates the cell death phenotype caused by the expression of mammalian Bax in plant cells. It indicates that EDS1 is functionally involved in Bax-induced cell death. However, it is still unknown how the HR is induced during Bax expression in plants, and more studies are required to explain this. Most importantly, we show that some of the molecular mechanism of cell death regulation are strongly preserved among living organisms and that they probably developed before the division of living organisms into plants and animals.

Supplementary Materials: The following are available online at http://www.mdpi.com/2073-4409/9/11/2454/s1. Supplementary Figure 1. The relative expression level of (A) EDS1 and (B) Bax in plants used in this study: within a subgraph, values sharing common labels (letters) are not significantly different from each other $(p>0.001)(n=9)$. Supplementary Figure 2. Phenotype of the wildtype, eds1 mutant, and Bax and eds1/Bax lines (+mock/+DEX). Supplementary Figure 3. Relative expression level of specific singlet oxygen $\left({ }^{1} \mathrm{O}_{2}\right)$ marker genes in the wildtype, eds1 mutant, and Bax and eds1/Bax lines for (A) BAP1 and (B) AAA-ATPase1: within a subgraph, values sharing common labels (letters) are not significantly different from each other $(p>0.001)(n=9)$. Supplementary Figure 4 . Relative expression level of hypersensitive response (HR) marker genes in the wildtype, eds1 mutant, and Bax and $e d s 1 / B a x$ lines for (A) NHL8 and (B) SAG101: within a subgraph, values sharing common labels (letters) are not significantly different from each other $(p>0.001)(n=9)$. Supplementary Figure 5 . The relative expression level of (A) MC1 and (B) MC2: within a subgraph, values sharing common labels (letters) are not significantly different from each other $(p>0.001)(n=8-10)$. Supplementary Figure 6. Chlorophyll fluorescence parameters: (A) photochemistry in the dark-adapted state $(\mathrm{Fv} / \mathrm{Fm}),(\mathrm{B})$ maximum quantum efficiency of photosystem II (PSII) photochemistry $\left(\mathrm{Fv}^{\prime} / \mathrm{Fm}^{\prime}\right),(\mathrm{C})$ effective quantum yield of PSII photochemistry $(\phi \mathrm{PSII})$, and $(\mathrm{D})$ non-photochemical quenching (NPQ). Within a subgraph, values sharing common labels (letters) are not significantly different from each other $(p>0.05)(n=18-22)$. Supplementary Table 1. List of primers used in this study. Supplementary Table 2. ROS marker genes used in this study.

Author Contributions: M.J.B., W.C. and S.K. were involved in the formulation, experimental design, and writeup of the manuscript. M.J.B. was involved in plant crossing, biometric analysis, relative electrolyte leakage measurement, TB staining, RNA isolation, and cDNA synthesis. M.Z. was involved in real-time PCR analysis, E.R. was involved in electromicroscopy. M.L. was involved in antioxidant system analysis. A.R. was involved in ROS measurement. D.W. was involved in DAB staining. All authors have read and agreed to the published version of the manuscript.

Funding: The work was funded by the "Maestro 6" project (2014/14/A/NZ1/00218) and by the "OPUS 16" project (UMO-2018/29/B/NZ3/01198) granted to Stanisław Karpiński by the National Science Centre.

Conflicts of Interest: The authors declare no conflict of interest. The funders had no role in the design of the study; in the collection, analyses, or interpretation of data; in the writing of the manuscript, or in the decision to publish the results.

\section{References}

1. Domínguez, F.; Cejudo, F.J. Programmed cell death (PCD): An essential process of cereal seed development and germination. Front. Plant Sci. 2014, 5, 366. [CrossRef] [PubMed]

2. Fukuda, H. Programmed cell death of tracheary elements as a paradigm in plants. Plant Mol. Biol. 2000, 44, 245-253. [CrossRef] [PubMed]

3. Jabs, T.; Dietrich, R.A.; Dangl, J.L. Initiation of runaway cell death in an Arabidopsis mutant by extracellular superoxide. Science 1996, 273, 1853-1856. [CrossRef] [PubMed]

4. Mühlenbock, P.; Plaszczyca, M.; Plaszczyca, M.; Mellerowicz, E.; Karpinski, S. Lysigenous Aerenchyma Formation in Arabidopsis Is Controlled by LESION SIMULATING DISEASE1. Plant Cell 2007, 19, 3819-3830. [CrossRef]

5. Elmore, S. Apoptosis: A Review of Programmed Cell Death. Toxicol. Pathol. 2007, 35, 495-516. [CrossRef] [PubMed]

6. Pennell, R.I.; Lamb, C. Programmed Cell Death in Plants. Plant Cell 1997, 9, 1157-1168. [CrossRef]

7. Kawai-Yamada, M.; Jin, L.; Yoshinaga, K.; Hirata, A.; Uchimiya, H. Mammalian Bax-induced plant cell death can be down-regulated by overexpression of Arabidopsis Bax Inhibitor-1 (AtBI-1). Proc. Natl. Acad. Sci. USA 2001, 98, 12295-12300. [CrossRef]

8. Lacomme, C.; Cruz, S.S. Bax-induced cell death in tobacco is similar to the hypersensitive response. Proc. Natl. Acad. Sci. USA 1999, 96, 7956-7961. [CrossRef]

9. Aravind, L.; Dixit, V.M.; Koonin, E.V. The domains of death: Evolution of the apoptosis machinery. Trends Biochem. Sci. 1999, 24, 47-53. [CrossRef] 
10. Schinzel, A.; Kaufmann, T.; Borner, C. Bcl-2 family members: Integrators of survival and death signals in physiology and pathology [corrected]. Biochim. Biophys. Acta 2004, 1644, 95-105. [CrossRef]

11. Youle, R.J.; Strasser, A. The BCL-2 protein family: Opposing activities that mediate cell death. Nat. Rev. Mol. Cell Biol. 2008, 9, 47-59. [CrossRef] [PubMed]

12. Kvansakul, M.; Yang, H.; Fairlie, W.D.; Czabotar, P.E.; Fischer, S.F.; Perugini, M.A.; Huang, D.C.S.; Colman, P.M. Vaccinia virus anti-apoptotic F1L is a novel Bcl-2-like domain-swapped dimer that binds a highly selective subset of BH3-containing death ligands. Cell Death Differ. 2008, 15, 1564-1571. [CrossRef] [PubMed]

13. Martinou, J.-C.; Youle, R.J. Mitochondria in Apoptosis: Bcl-2 Family Members and Mitochondrial Dynamics. Dev. Cell 2011, 21, 92-101. [CrossRef] [PubMed]

14. Vaux, D.L. Apoptogenic factors released from mitochondria. Biochim. Biophys. Acta 2011, 1813, 546-550. [CrossRef] [PubMed]

15. Kroemer, G.; Galluzzi, L.; Brenner, C. Mitochondrial membrane permeabilization in cell death. Physiol. Rev. 2007, 87, 99-163. [CrossRef] [PubMed]

16. Yoshinaga, K.; Arimura, S.; Hirata, A.; Niwa, Y.; Yun, D.-J.; Tsutsumi, N.; Uchimiya, H.; Kawai-Yamada, M. Mammalian Bax initiates plant cell death through organelle destruction. Plant Cell Rep. 2005, 24, 408-417. [CrossRef]

17. Baek, D.; Nam, J.; Koo, Y.D.; Kim, D.H.; Lee, J.; Jeong, J.C.; Kwak, S.; Chung, W.S.; Lim, C.O.; Bahk, J.D.; et al. Bax-induced cell death of is meditated through reactive oxygen-dependent and -independent processes. Plant Mol. Biol. 2004, 56, 15-27. [CrossRef]

18. Sanchez, P.; Zabala, M.D.T.; Grant, M. AtBI-1, a plant homologue of Bax Inhibitor-1, suppresses Bax-induced cell death in yeast and is rapidly upregulated during wounding and pathogen challenge. Plant J. 2000, 21, 393-399. [CrossRef]

19. Watanabe, N.; Lam, E. Arabidopsis Bax inhibitor-1 functions as an attenuator of biotic and abiotic types of cell death. Plant J. 2006, 45, 884-894. [CrossRef]

20. Wituszyńska, W.; Szechyńska-Hebda, M.; Sobczak, M.; Rusaczonek, A.; Kozłowska-Makulska, A.; Witoń, D.; Karpiński, S. Lesion simulating disease 1 and enhanced disease susceptibility 1 differentially regulate UV-C-induced photooxidative stress signalling and programmed cell death in Arabidopsis thaliana. Plant Cell Environ. 2015, 38, 315-330. [CrossRef]

21. Gilroy, S.; Białasek, M.; Suzuki, N.; Górecka, M.; Devireddy, A.R.; Karpiński, S.; Mittler, R. ROS, Calcium, and Electric Signals: Key Mediators of Rapid Systemic Signaling in Plants. Plant Physiol. 2016, 171, 1606-1615. [CrossRef] [PubMed]

22. Karpiński, S.; Szechyńska-Hebda, M.; Wituszyńska, W.; Burdiak, P. Light acclimation, retrograde signalling, cell death and immune defences in plants. Plant Cell Environ. 2013, 36, 736-744. [CrossRef] [PubMed]

23. Aoyama, T.; Chua, N.H. A glucocorticoid-mediated transcriptional induction system in transgenic plants. Plant J. Cell Mol. Biol. 1997, 11, 605-612. [CrossRef] [PubMed]

24. Glazebrook, J.; Rogers, E.E.; Ausubel, F.M. Isolation of Arabidopsis Mutants with Enhanced Disease Susceptibility by Direct Screening. Genetics 1996, 143, 973-982.

25. Parker, J.E.; Holub, E.B.; Frost, L.N.; Falk, A.; Gunn, N.D.; Daniels, M.J. Characterization of EDS1, a mutation in Arabidopsis suppressing resistance to Peronospora parasitica specified by several different $R P P$ genes. Plant Cell 1996, 8, 2033-2046.

26. Falk, A.; Feys, B.J.; Frost, L.N.; Jones, J.D.G.; Daniels, M.J.; Parker, J.E. EDS1, an essential component of R gene-mediated disease resistance in Arabidopsis has homology to eukaryotic lipases. Proc. Natl. Acad. Sci. USA 1999, 96, 3292-3297. [CrossRef]

27. Bernacki, M.J.; Czarnocka, W.; Rusaczonek, A.; Witoń, D.; Kęska, S.; Czyż, J.; Szechyńska-Hebda, M.; Karpiński, S. LSD1, EDS1 and PAD4-dependent conditional correlation among salicylic acid, hydrogen peroxide, water use efficiency, and seed yield in Arabidopsis thaliana. Physiol. Plant. 2018, 165, 369-382. [CrossRef]

28. Mateo, A.; Mühlenbock, P.; Rustérucci, C.; Chang, C.C.-C.; Miszalski, Z.; Karpinska, B.; Parker, J.E.; Mullineaux, P.M.; Karpinski, S. LESION SIMULATING DISEASE 1 is required for acclimation to conditions that promote excess excitation energy. Plant Physiol. 2004, 136, 2818-2830. [CrossRef]

29. Chen, Q.-F.; Xu, L.; Tan, W.-J.; Chen, L.; Qi, H.; Xie, L.-J.; Chen, M.-X.; Liu, B.-Y.; Yu, L.-J.; Yao, N.; et al. Disruption of the Arabidopsis Defense Regulator Genes SAG101, EDS1, and PAD4 Confers Enhanced Freezing Tolerance. Mol. Plant 2015, 8, 1536-1549. [CrossRef] 
30. Jirage, D.; Tootle, T.L.; Reuber, T.L.; Frost, L.N.; Feys, B.J.; Parker, J.E.; Ausubel, F.M.; Glazebrook, J. Arabidopsis thaliana PAD4 encodes a lipase-like gene that is important for salicylic acid signaling. Proc. Natl. Acad. Sci. USA 1999, 96, 13583-13588. [CrossRef]

31. Rietz, S.; Stamm, A.; Malonek, S.; Wagner, S.; Becker, D.; Medina-Escobar, N.; Vlot, A.C.; Feys, B.J.; Niefind, K.; Parker, J.E. Different roles of Enhanced Disease Susceptibility1 (EDS1) bound to and dissociated from Phytoalexin Deficient4 (PAD4) in Arabidopsis immunity. New Phytol. 2011, 191, 107-119. [CrossRef] [PubMed]

32. Feys, B.J.; Moisan, L.J.; Newman, M.-A.; Parker, J.E. Direct interaction between the Arabidopsis disease resistance signaling proteins, EDS1 and PAD4. EMBO J. 2001, 20, 5400-5411. [CrossRef] [PubMed]

33. Feys, B.J.; Wiermer, M.; Bhat, R.A.; Moisan, L.J.; Medina-Escobar, N.; Neu, C.; Cabral, A.; Parker, J.E. Arabidopsis SENESCENCE-ASSOCIATED GENE101 stabilizes and signals within an ENHANCED DISEASE SUSCEPTIBILITY1 complex in plant innate immunity. Plant Cell 2005, 17, 2601-2613. [CrossRef] [PubMed]

34. Zhu, S.; Jeong, R.-D.; Venugopal, S.C.; Lapchyk, L.; Navarre, D.; Kachroo, A.; Kachroo, P. SAG101 Forms a Ternary Complex with EDS1 and PAD4 and Is Required for Resistance Signaling against Turnip Crinkle Virus. PLOS Pathog. 2011, 7, e1002318. [CrossRef]

35. Czarnocka, W.; Van Der Kelen, K.; Willems, P.; Szechynska-Hebda, M.; Shahnejat-Bushehri, S.; Balazadeh, S.; Rusaczonek, A.; Mueller-Roeber, B.; Van Breusegem, F.; Karpinski, S. The dual role of LESION SIMULATING DISEASE 1 as a condition-dependent scaffold protein and transcription regulator. Plant Cell Environ. 2017, 40, 2644-2662. [CrossRef]

36. Oracz, K.; Karpiński, S. Phytohormones Signaling Pathways and ROS Involvement in Seed Germination. Front. Plant Sci. 2016, 7. [CrossRef]

37. Hruz, T.; Laule, O.; Szabo, G.; Wessendorp, F.; Bleuler, S.; Oertle, L.; Widmayer, P.; Gruissem, W.; Zimmermann, P. Genevestigator v3: A reference expression database for the meta-analysis of transcriptomes. Adv. Bioinform. 2008, 2008, 420747. [CrossRef]

38. Ramakers, C.; Ruijter, J.M.; Deprez, R.H.L.; Moorman, A.F.M. Assumption-free analysis of quantitative real-time polymerase chain reaction (PCR) data. Neurosci. Lett. 2003, 339, 62-66. [CrossRef]

39. Pfaffl, M.W.; Horgan, G.W.; Dempfle, L. Relative expression software tool (RESTC) for group-wise comparison and statistical analysis of relative expression results in real-time PCR. Nucleic Acids Res. 2002, 30, e36. [CrossRef]

40. Golinowski, W.; Grundler, F.M.W.; Sobczak, M. Changes in the structure ofArabidopsis thaliana during female development of the plant-parasitic nematode Heterodera schachtii. Protoplasma 1996, 194, $103-116$. [CrossRef]

41. Labudda, M.; Różańska, E.; Czarnocka, W.; Sobczak, M.; Dzik, J.M. Systemic changes in photosynthesis and reactive oxygen species homeostasis in shoots of Arabidopsis thaliana infected with the beet cyst nematode Heterodera schachtii. Mol. Plant Pathol. 2018, 19, 1690-1704. [CrossRef] [PubMed]

42. Spector, T. Refinement of the coomassie blue method of protein quantitation. A simple and linear spectrophotometric assay for less than or equal to 0.5 to 50 microgram of protein. Anal. Biochem. 1978, 86, 142-146. [CrossRef]

43. Kostyuk, V.A.; Potapovich, A.I. Superoxide-Driven oxidation of quercetin and a simple sensitive assay for determination of superoxide dismutase. Biochem. Int. 1989, 19, 1117-1124. [PubMed]

44. Rusaczonek, A.; Czarnocka, W.; Kacprzak, S.; Witoń, D.; Ślesak, I.; Szechyńska-Hebda, M.; Gawroński, P.; Karpiński, S. Role of phytochromes A and B in the regulation of cell death and acclimatory responses to UV stress in Arabidopsis thaliana. J. Exp. Bot. 2015, 66, 6679-6695. [CrossRef]

45. Czarnocka, W.; Karpiński, S. Friend or foe? Reactive oxygen species production, scavenging and signaling in plant response to environmental stresses. Free Radic. Biol. Med. 2018, 122, 4-20. [CrossRef]

46. Zurbriggen, M.D.; Carrillo, N.; Hajirezaei, M.-R. ROS signaling in the hypersensitive response. Plant Signal. Behav. 2010, 5, 393-396. [CrossRef]

47. Rustérucci, C.; Aviv, D.H.; Holt, B.F.; Dangl, J.L.; Parker, J.E. The disease resistance signaling components EDS1 and PAD4 are essential regulators of the cell death pathway controlled by LSD1 in Arabidopsis. Plant Cell 2001, 13, 2211-2224. [CrossRef]

48. Gadjev, I.; Vanderauwera, S.; Gechev, T.S.; Laloi, C.; Minkov, I.N.; Shulaev, V.; Apel, K.; Inzé, D.; Mittler, R.; Breusegem, F.V. Transcriptomic Footprints Disclose Specificity of Reactive Oxygen Species Signaling in Arabidopsis. Plant Physiol. 2006, 141, 436-445. [CrossRef] 
49. Czarnocka, W.; Fichman, Y.; Bernacki, M.; Różańska, E.; Sańko-Sawczenko, I.; Mittler, R.; Karpiński, S. FMO1 Is Involved in Excess Light Stress-Induced Signal Transduction and Cell Death Signaling. Cells 2020, 9, 2163. [CrossRef]

50. Op den Camp, R.G.L.; Przybyla, D.; Ochsenbein, C.; Laloi, C.; Kim, C.; Danon, A.; Wagner, D.; Hideg, E.; Göbel, C.; Feussner, I.; et al. Rapid induction of distinct stress responses after the release of singlet oxygen in Arabidopsis. Plant Cell 2003, 15, 2320-2332. [CrossRef]

51. Carmody, M.; Crisp, P.A.; d'Alessandro, S.; Ganguly, D.; Gordon, M.; Havaux, M.; Albrecht-Borth, V.; Pogson, B.J. Uncoupling High Light Responses from Singlet Oxygen Retrograde Signaling and Spatial-Temporal Systemic Acquired Acclimation1[OPEN]. Plant Physiol. 2016, 171, 1734-1749. [CrossRef] [PubMed]

52. Pontier, D.; Gan, S.; Amasino, R.M.; Roby, D.; Lam, E. Markers for hypersensitive response and senescence show distinct patterns of expression. Plant Mol. Biol. 1999, 39, 1243-1255. [CrossRef] [PubMed]

53. Clarke, J.D.; Aarts, N.; Feys, B.J.; Dong, X.; Parker, J.E. Constitutive disease resistance requires EDS1 in the Arabidopsis mutants cpr1 and cpr6 and is partially EDS1-dependent in cpr5. Plant J. Cell Mol. Biol. 2001, 26, 409-420. [CrossRef] [PubMed]

54. Xing, D.; Chen, Z. Effects of mutations and constitutive overexpression of EDS1 and PAD4 on plant resistance to different types of microbial pathogens. Plant Sci. 2006, 171, 251-262. [CrossRef]

55. Lohman, K.N.; Gan, S.; John, M.C.; Amasino, R.M. Molecular analysis of natural leaf senescence in Arabidopsis thaliana. Physiol. Plant. 1994, 92, 322-328. [CrossRef]

56. Lord, C.E.N.; Gunawardena, A.H.L.A.N. Environmentally induced programmed cell death in leaf protoplasts of Aponogeton madagascariensis. Planta 2011, 233, 407-421. [CrossRef]

57. Fagundes, D.; Bohn, B.; Cabreira, C.; Leipelt, F.; Dias, N.; Bodanese-Zanettini, M.H.; Cagliari, A. Caspases in plants: Metacaspase gene family in plant stress responses. Funct. Integr. Genomics 2015, 15, 639-649. [CrossRef]

58. Yu, L.-H.; Kawai-Yamada, M.; Naito, M.; Watanabe, K.; Reed, J.C.; Uchimiya, H. Induction of mammalian cell death by a plant Bax inhibitor. FEBS Lett. 2002, 512, 308-312. [CrossRef]

59. Alvarez, M.E.; Pennell, R.I.; Meijer, P.J.; Ishikawa, A.; Dixon, R.A.; Lamb, C. Reactive oxygen intermediates mediate a systemic signal network in the establishment of plant immunity. Cell 1998, 92, 773-784. [CrossRef]

60. Wang, P.-C.; Du, Y.-Y.; An, G.-Y.; Zhou, Y.; Miao, C.; Song, C.-P. Analysis of Global Expression Profiles of Arabidopsis Genes Under Abscisic Acid and $\mathrm{H}_{2} \mathrm{O}_{2}$ Applications. J. Integr. Plant Biol. 2006, 48, 62-74. [CrossRef]

61. Kliebenstein, D.J.; Monde, R.A.; Last, R.L. Superoxide dismutase in Arabidopsis: An eclectic enzyme family with disparate regulation and protein localization. Plant Physiol. 1998, 118, 637-650. [CrossRef] [PubMed]

62. Starkov, A.A.; Polster, B.M.; Fiskum, G. Regulation of hydrogen peroxide production by brain mitochondria by calcium and Bax. J. Neurochem. 2002, 83, 220-228. [CrossRef] [PubMed]

63. Melis, A. Photosystem-II damage and repair cycle in chloroplasts: What modulates the rate of photodamage in vivo? Trends Plant Sci. 1999, 4, 130-135. [CrossRef]

64. Pospíšil, P. Production of reactive oxygen species by photosystem II. Biochim. Biophys. Acta BBA-Bioenerg. 2009, 1787, 1151-1160. [CrossRef]

65. Asada, K. Production and scavenging of reactive oxygen species in chloroplasts and their functions. Plant Physiol. 2006, 141, 391-396. [CrossRef]

66. Bernacki, M.J.; Czarnocka, W.; Witoń, D.; Rusaczonek, A.; Szechyńska-Hebda, M.; Ślesak, I.; Dąbrowska-Bronk, J.; Karpiński, S. ENHANCED DISEASE SUSCEPTIBILITY 1 (EDS1) affects development, photosynthesis, and hormonal homeostasis in hybrid aspen (Populus tremula L. $\times$ P. tremuloides). J. Plant Physiol. 2018, 226, 91-102. [CrossRef]

67. Morel, J.-B.; Dangl, J.L. The hypersensitive response and the induction of cell death in plants. Cell Death Differ. 1997, 4, 671-683. [CrossRef]

68. Lam, E.; Kato, N.; Lawton, M. Programmed cell death, mitochondria and the plant hypersensitive response. Nature 2001, 411, 848-853. [CrossRef]

69. Green, R.; Fluhr, R. UV-B-Induced PR-1 Accumulation Is Mediated by Active Oxygen Species. Plant Cell 1995, 7, 203-212. [CrossRef]

70. Mur, L.A.J.; Kenton, P.; Lloyd, A.J.; Ougham, H.; Prats, E. The hypersensitive response; the centenary is upon us but how much do we know? J. Exp. Bot. 2008, 59, 501-520. [CrossRef] 
71. McLellan, H.; Gilroy, E.M.; Yun, B.-W.; Birch, P.R.J.; Loake, G.J. Functional redundancy in the Arabidopsis Cathepsin B gene family contributes to basal defence, the hypersensitive response and senescence. New Phytol. 2009, 183, 408-418. [CrossRef]

72. El Oirdi, M.; Bouarab, K. Plant signalling components EDS1 and SGT1 enhance disease caused by the necrotrophic pathogen Botrytis cinerea. New Phytol. 2007, 175, 131-139. [CrossRef]

73. Peng, J.-L.; Dong, H.-S.; Dong, H.-P.; Delaney, T.P.; Bonasera, J.M.; Beer, S.V. Harpin-elicited hypersensitive cell death and pathogen resistance require the NDR1 and EDS1 genes. Physiol. Mol. Plant Pathol. 2003, 62, 317-326. [CrossRef]

74. Hu, G.; de Hart, A.K.A.; Li, Y.; Ustach, C.; Handley, V.; Navarre, R.; Hwang, C.-F.; Aegerter, B.J.; Williamson, V.M.; Baker, B. EDS1 in tomato is required for resistance mediated by TIR-class R genes and the receptor-like R gene Ve. Plant J. Cell Mol. Biol. 2005, 42, 376-391. [CrossRef]

75. Clarke, J.D.; Liu, Y.; Klessig, D.F.; Dong, X. Uncoupling PR gene expression from NPR1 and bacterial resistance: Characterization of the dominant Arabidopsis cpr6-1 mutant. Plant Cell 1998, 10, 557-569. [CrossRef]

76. Aarts, N.; Metz, M.; Holub, E.; Staskawicz, B.J.; Daniels, M.J.; Parker, J.E. Different requirements for EDS1 and NDR1 by disease resistance genes define at least two R gene-mediated signaling pathways in Arabidopsis. Proc. Natl. Acad. Sci. USA 1998, 95, 10306-10311. [CrossRef]

77. Coll, N.S.; Vercammen, D.; Smidler, A.; Clover, C.; Van Breusegem, F.; Dangl, J.L.; Epple, P. Arabidopsis type I metacaspases control cell death. Science 2010, 330, 1393-1397. [CrossRef]

78. Watanabe, N.; Lam, E. BAX Inhibitor-1 Modulates Endoplasmic Reticulum Stress-mediated Programmed Cell Death in Arabidopsis. J. Biol. Chem. 2008, 283, 3200-3210. [CrossRef]

79. Kołodziejek, I.; Kozioł, J.; Wałęza, M.; Mostowska, A. Ultrastructure of Mesophyll Cells and Pigment Content in Senescing Leaves of Maize and Barley. J. Plant Growth Regul. 2003, 22, 217-227. [CrossRef]

80. Kawai-Yamada, M.; Ohori, Y.; Uchimiya, H. Dissection of Arabidopsis Bax Inhibitor-1 Suppressing Bax-, Hydrogen Peroxide-, and Salicylic Acid-Induced Cell Death. Plant Cell 2004, 16, 21-32. [CrossRef]

81. Greenhalf, W.; Stephan, C.; Chaudhuri, B. Role of mitochondria and C-terminal membrane anchor of Bcl-2 in Bax induced growth arrest and mortality in Saccharomyces cerevisiae. FEBS Lett. 1996, 380, 169-175. [CrossRef]

82. Scherz-Shouval, R.; Elazar, Z. Regulation of autophagy by ROS: Physiology and pathology. Trends Biochem. Sci. 2011, 36, 30-38. [CrossRef] [PubMed]

83. Naderi, J.; Somayajulu-Nitu, M.; Mukerji, A.; Sharda, P.; Sikorska, M.; Borowy-Borowski, H.; Antonsson, B.; Pandey, S. Water-soluble formulation of Coenzyme Q10 inhibits Bax-induced destabilization of mitochondria in mammalian cells. Apoptosis 2006, 11, 1359-1369. [CrossRef] [PubMed]

84. Møller, I.M.; Sweetlove, L.J. ROS signalling-Specificity is required. Trends Plant Sci. 2010, 15, 370-374. [CrossRef]

85. Galvez-Valdivieso, G.; Mullineaux, P.M. The role of reactive oxygen species in signalling from chloroplasts to the nucleus. Physiol. Plant. 2010, 138, 430-439. [CrossRef]

Publisher's Note: MDPI stays neutral with regard to jurisdictional claims in published maps and institutional affiliations.

(C) 2020 by the authors. Licensee MDPI, Basel, Switzerland. This article is an open access article distributed under the terms and conditions of the Creative Commons Attribution (CC BY) license (http://creativecommons.org/licenses/by/4.0/). 